\title{
ANÁLISE DOS IMPACTOS AMBIENTAIS NA BACIA HIDROGRÁFICA DO RIO PARAGUAI - CÁCERES/MT: RISCO ECOLÓGICO PARA O PANTANAL MATOGROSSENSE
}

\author{
Ana Rosa Ferreira ${ }^{(1)}$, Miguel Castilho Junior ${ }^{(2)}$, Marta Maria Francisca de Souza ${ }^{(3)}$ \\ ${ }^{(1)}$ Departamento de Geografia, Faculdade de Ciências Humanas, Universidade do Estado de Mato Grosso \\ - ferreiraar2004@ hotmail.com \\ ${ }^{(2)}$ Departamento de Geografia, Faculdade de Ciências Humanas, Universidade do Estado de Mato Grosso \\ -migueljunior@unemat.br \\ (3) Departamento de Geografia, Faculdade de Ciências Humanas, Universidade do Estado de Mato Grosso \\ - $\underline{\text { mmfsouza@ hotmail.com }}$
}

\section{EIXO: BACIAS HIDROGRÁFICAS E RECURSOS HÍDRICOS: ANÁLISE, PLANEJAMENTO E GESTÃO}

\begin{abstract}
Resumo
A água é um recurso finito e vulnerável, essencial para sustentar a vida. A escassez e o mau uso desse recurso são fatores de crescente risco ao desenvolvimento sustentável e a proteção do meio ambiente. A população produtora de resíduos sólidos não se preocupa com o destino final desse produto, principalmente porque é um dos principais responsáveis pela poluição ambiental do planeta. O pressente trabalho objetivou o levantamento e análise de dois impactos ocorrentes na cidade de Cáceres, o lixão e o Córrego do Junco. Para tanto realizou-se uma análise voltada para os eventos atuais, ou seja, as visitas in loco gerando resultados. A água do referido córrego é imprópria para o uso humano e não gestão dos resíduos sólidos no lixão da cidade, o que compromete a qualidade do solo, podendo, dessa forma contaminar o lençol freático.
\end{abstract}

Palavras-chave: impactos ambientais, pantanal, lençol freático, solo.

\section{1 - INTRODUÇÃO}

Segundo parâmetros designados pela Constituição Federal: todos têm direito ao meio ambiente ecologicamente equilibrado, bem de uso comum do povo e essencial à sadia qualidade de vida, impondo-se ao Poder Público e a coletividade o dever de defendê-lo e preservá-lo para as futuras gerações (FIGUEIREDO, 2000).

Entretanto, o que se vê a degradação dos recursos naturais: solos, vegetação e água, pela intensa exploração econômica e contaminação por resíduos descartados pela população, comércio e indústrias.

Para Müller-Plantenberg e Ab’Saber (2002) impacto significa "choque" ou "colisão", impacto ambiental portanto é; qualquer alteração das propriedades físicas, químicas e biológicas do meio ambiente, causada por qualquer forma de matéria ou energia resultante das atividades humanas que direta ou indiretamente afetam: a saúde, a segurança e o bem-estar da população, 
as atividades sociais e econômicas; a biota; as condições estéticas e sanitárias do meio ambiente e,a qualidade dos recursos ambientais.

Dessa forma, Conte e Leopoldo (2001), abordam que a preocupação com a degradação e o esgotamento dos recursos hídricos vem sendo tema constante de debates em todo o mundo, principalmente em países como a França, Alemanha e Inglaterra entre outros, que perceberam a necessidade de se implantar uma legislação específica relacionada ao uso da água.

Tundisi (2003) mostra que a água tem sido utilizada na agricultura, na produção de suínos e aves, na utilização doméstica, navegação, turismo, enfim, nas mais diversas atividades humanas. Este mesmo autor mostra que o ser humano para satisfazer suas funções vitais necessita de, no mínimo, cinco (5) litros de água por dia para beber e cozinhar e 25 litros para higiene pessoal. Uma família média consome cerca de 350 litros de água no Canadá, 20 litros na África, 165 litros na Europa e 200 litros no Brasil.

Analisando o direito brasileiro sobre bacias hidrográficas constatou-se que, o que está ocorrendo é totalmente o inverso, as pessoas não se preocupam em preservar o que foi útil para si, portanto não terá importância para as futuras gerações já que só haverá sinais da degradação. Enfatizar o melhoramento da qualidade da água é um elemento importante das estratégias de redução da pobreza (COUTINHO e ROCCO, 2004).

De acordo com Esteves (1998) a água constitui um dos compostos de maior distribuição e importância na crosta terrestre. Sua importância para a vida está no fato de que nenhum processo metabólico ocorre sem a sua ação direta ou indireta. Porém, não é isso que estudos mostram, o uso múltiplo das águas superficiais e subterrâneas tem saciado a necessidade humana em diversas partes do mundo, mas em alguns países como a França já há racionamentos de água e esse fenômeno se dará com maior freqüência se a poluição dos mananciais continuarem a "galope".

Os resíduos sólidos são materiais heterogêneos (inertes, minerais e orgânicos) resultantes das atividades humanas e da natureza, os quais podem ser parcialmente utilizados, gerando, entre outros aspectos, proteção à saúde pública e economia de recursos naturais. Os resíduos sólidos constituem problemas sanitários, econômicos e principalmente estéticos, também são denominados popularmente por "lixo".

Com o depósito dos resíduos nos locais denominados lixões, ao longo dos anos, é notório o comprometimento dos mananciais hídricos próximo ao local de depósito, prejudicando também as pessoas que moram ao seu entorno, através de doenças causadas pela grande proliferação de insetos e pelo forte odor.

Para Oliveira et al (1991) a falta de ações conjuntas de políticas públicas de limpezas urbanas e conscientização da população, ocasionam o lançamento de resíduos na natureza de 
forma desordenada, sendo descartados em terrenos, valas e canais, ocasionando assoreamento de rios canais e proporcionando a proliferação de insetos e animais vetores de doenças.

A grande concentração da população em algumas regiões, cidades e áreas metropolitanas têm sido um dos principais aspectos que deve ser considerado na gestão integrada de recursos hídricos, fato que implica em demanda por disponibilidade de água para abastecimento público e também para a dissolução de cargas poluidoras urbanas. No Brasil a poluição hídrica vem se agravando consideravelmente, através do aumento de detritos urbano e industrial, uso inadequado, erosão, desmatamento, uso inadequado de insumos agrícolas e mineração. Estes fatores, quando associados à distribuição anual das chuvas e às condições climáticas causam impactos consideráveis sobre os recursos hídricos (GUERRA e CUNHA, 2001).

O gerenciamento da água como bem de valor econômico é um meio importante para atingir o seu uso eficiente e eqüitativo, e um incentivo à sua conservação proteção e uso racional. No Brasil, a gestão dos recursos hídricos nos últimos anos tem sido merecedora de grandes discussões em razão da degradação tanto qualitativa quanto quantitativa desses recursos. No início essas discussões giravam em torno de problemas fundamentalmente relacionados à produção energética, ao armazenamento e a contenção das cheias, por meio de construção de barragens (GUERRA e CUNHA, 2001).

O lançamento de resíduos industriais e/ou domésticos indiscriminadamente nos cursos d'água, como forma de destino final, poderá ocorrer assoreamento além do aumento da turbidez e variação do gradiente de temperatura, acarretando a quebra do ciclo vital das espécies, tornando a água biologicamente estéril. O lançamento de despejos industriais com temperatura elevada afeta a sobrevivência de algumas espécies da fauna e flora aquática, visto que a vida destas espécies só pode existir dentro de um gradiente relativamente pequeno de temperatura.

Da mesma forma, o depósito de lixo em locais inadequados e a céu aberto acarreta não só contaminação do lençol freático, como do próprio solo e por consequiência, quando utilizam da queima do mesmo, pode produzir a poluição atmosférica. Vale ressaltar que há a contaminação de muitas espécies animais que procuram esses locais para se alimentar.

Na cidade de Cáceres-MT essa situação não é diferente, pois com o incentivo ao consumismo e o crescimento populacional, aumenta cada vez mais o número da produção dos resíduos sólidos. Esses resíduos são depositados em um local a céu aberto, que se localiza a 13 km da cidade de Cáceres-MT, à margem esquerda da MT 343 que liga Cáceres ao município de Barra do Bugres, e a montante do córrego das Piraputangas, muito freqüentado por turista e pela população local. 
Sendo assim essa pesquisa visa analisar a disposição final e propor projetos de gestão e gerenciamento dos resíduos sólidos no município de Cáceres-MT. Para tanto será necessário identificar o tipo de disposição final dos resíduos sólidos em Cáceres-MT, bem como avaliar os impactos ambientais decorrentes do tipo de disposição para propor projetos que visam a gestão e o gerenciamento da disposição final dos resíduos sólidos em Cáceres-MT. E identificar os impactos ambientais no córrego do Junco decorrentes do descarte de lixo, procurando analisar junto aos moradores das margens do referido córrego, a percepção destes sobre os impactos e possíveis ações que visem minimizar a degradação ambiental dos recursos hídricos.

\section{2 - PROCEDIMENTOS METODOLÓGICOS}

\section{1 - Caracterização da Área e Estudo 1:}

A área a ser estudada é denominado popularmente como "lixão", distante a $13 \mathrm{~km}$ da cidade de Cáceres/MT, à margem esquerda da MT 343 que liga cidade à Barra do Bugres, e a montante do córrego das Piraputangas, muito freqüentado por turista e pela população local, conforme figura 1.

A bacia do Córrego das Piraputangas com $170 \mathrm{~km}^{2}$, situa-se no município de Cáceres, à sudoeste do Estado de Mato Grosso, entre as coordenadas $15^{\circ} 57^{\prime}$ e $16^{\circ} 12^{\prime}$ de latitude $\mathrm{S}$ e $57^{\circ}$ $30^{\prime}$ e $57^{\circ} 42^{\prime}$ de longitude W. A bacia hidrográfica tem como rio principal o córrego das Piraputangas, cujos formadores nascem nas serras da Província Serrana, e percorre áreas de diferentes compartimentos litológicos, geomorfológicos e topográficos. Encontra-se inserida entre dois ecossistemas de grande importância: cerrado e pantanal. As altitudes do relevo variam entre 116m a 609 m e o rio principal deságua na margem esquerda do rio Paraguai.
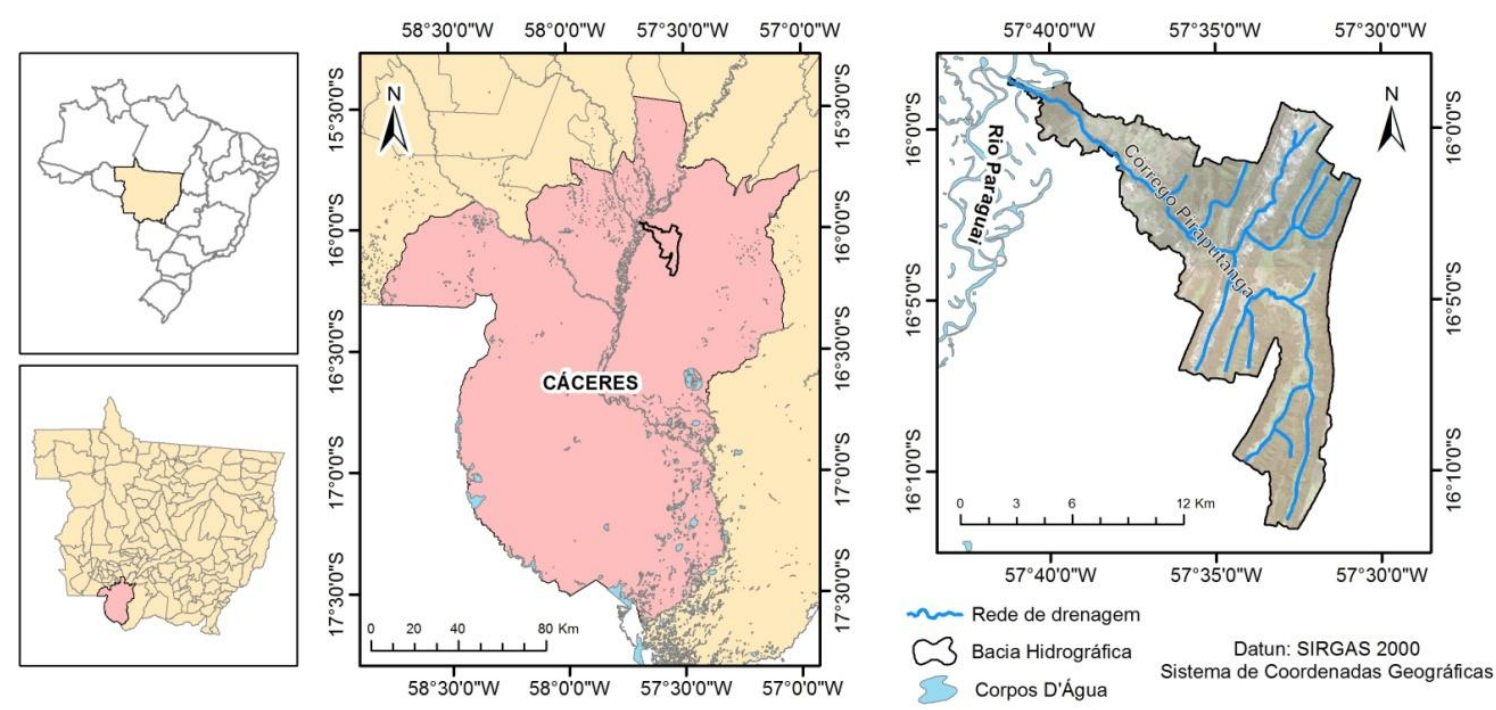

Figura 1: Localização da área do lixão na bacia hidrográfica do córrego das Piraputangas, Cáceres-MT.

\section{2 - Caracterização da área de estudo 2:}


A área de estudo escolhida foi o perímetro urbano da cidade de Cáceres, mais precisamente o percurso do córrego do Junco, que passa por alguns bairros chegando a desaguar no Rio Paraguai, conforme figura 2. A nascente do córrego do Junco situa-se dentro do bairro Santo Antônio em uma propriedade rural e apresenta as coordenadas geográficas S $16^{\circ} 07^{\prime}$ 45,22" e W $057^{\circ} 40^{\prime} 12,87^{\prime}$ " com altitude de $143 \mathrm{~m}$. A foz do córrego Junco que deságua no Rio Paraguai, apresenta as coordenadas geográficas S $16^{\circ} 05^{\prime} 55,52^{\prime \prime}$ e W $057^{\circ} 42^{\prime} 46,35^{\prime \prime}$ com altitude de $117 \mathrm{~m}$.
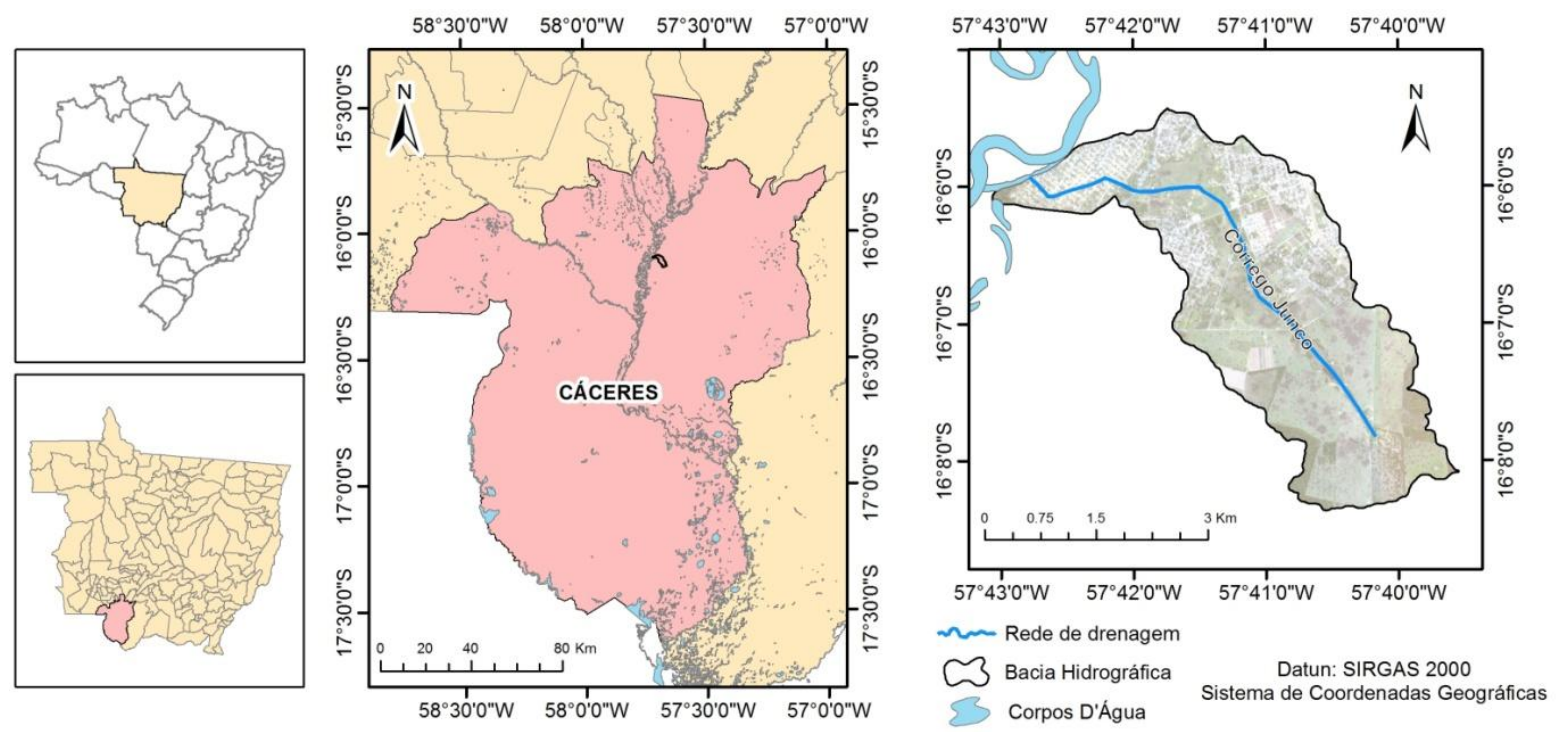

Figura 2: Localização do município de Cáceres-MT, evidenciando o Córrego do Junco da sua nascente a sua foz no Rio Paraguai - Cáceres/MT.

\section{3 - MATERIAL E MÉTODOS}

Para a construção da presente pesquisa foram utilizados os seguintes métodos:

*Localização do lixão, por meio de imagens de satélite e georreferenciamento, para produção de mapas de localização, ocupação e uso do solo;

*Observações "in loco", bem como registros fotográficos do local, nessa etapa foi possível identificar a disposição final dos resíduos sólidos da cidade de Cáceres e de que maneira os moradores próximos do local tem acesso irrestrito e coletam o que pode ser vendido ou mesmo reaproveitaado;

*Localização do córrego do Junco, nas imediações do bairro de mesmo nome e nas proximidades do bairro Vila Real, buscando registrar as condições físicas das margens e leito do referido córrego e a visão dos moradores que utilizam do mesmo; 
*Análise química, física e bacteriológica das condições da água no local, conforme análises laboratoriais, enviadas para Cuiabá, mediante métodos provenientes do Standard Methods for theExaminationofWaterandWastewater, $20^{\mathrm{a}}$ ed.

*Tabulação dos dados que fundamentarão a proposta de gestão e gerenciamento dos resíduos sólidos que serão elaboradas.

\section{4 - RESULTADOS E DISCUSSÕES}

\subsection{Registro das Condições do Lixão: Disposição Final dos Resíduos Sólidos:}

Uma das mais conhecidas áreas turística de Cáceres, a região das Piraputangas, a 15 quilômetros do perímetro urbano, pode estar condenada pela poluição. Toneladas de lixo, comercial, residencial e até hospitalar são despejados diariamente, no chamado "lixão" onde se concentra uma das maiores bacias hidrográficas do município.

Além do chorume gerado pela degradação dos resíduos do lixo, contendo alta carga poluidora absorvida pelo solo, e várias nascentes na encosta da formação rochosa, o córrego denominado "Pita Canudo" que passa na área do lixão deságua na Piraputangas, levando todo tipo de dejeto.

Em estudo realizado por ambientalistas em 2001, concluiu que a área é totalmente inadequada para depósito de lixo. À época já se recomendava providências emergenciais a fim de se evitar prejuízos à saúde e ao meio ambiente. Apesar dos indícios de contaminação e denuncias dos moradores não se tem conhecimento de qualquer pesquisa para constatação do índice de poluição na água e solo da comunidade.

Um dos maiores problemas enfrentados pela cidade de Cáceres no que se refere a disposição final dos resíduos sólidos é o gerenciamento dos resíduos sólidos produzidos, principalmente, no que tange à sua destinação. Condições inadequadas de descarte desses resíduos podem provocar inúmeros danos ao ambiente. A questão da disposição final do lixo urbano, apesar de ser um dos principais pontos relacionados com o saneamento básico das cidades, na maioria das vezes ainda permanece sem solução.

A disposição final do lixo é a céu aberto, algumas famílias catam materiais que podem ser recicláveis, materiais orgânicos e o restante é empurrado por uma máquina e despejado em uma vala que é coberta por terra, conforme figura 3 a seguir. 


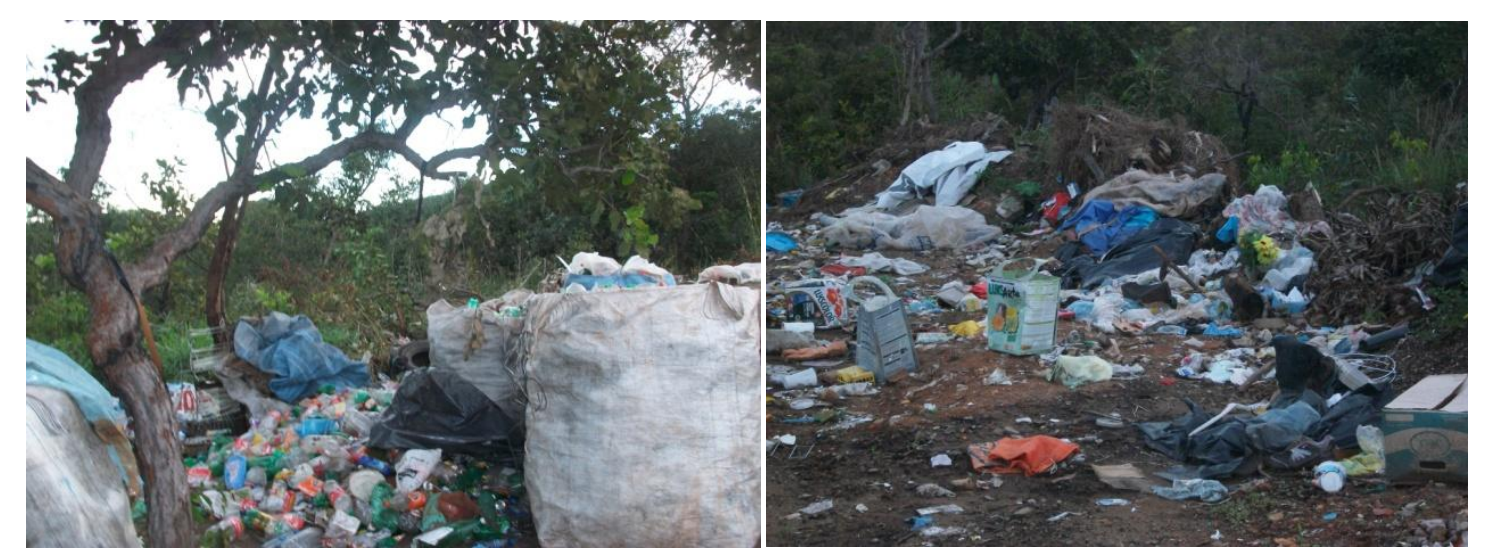

Figura 3: Vista parcial da disposição a céu aberto dos resíduos sólidos produzidos na cidade de CáceresMT.

Cáceres enfrenta problemas ligados a gestão dos resíduos sólidos, não tendo projetos que visem a reciclagem dos materiais e disposição final dos que não serão reciclados.Os sistemas designados a promover a coleta, o transporte e a destinação final do lixo urbano encontram-se vinculados às administração municipal e, nesse sentido, um dos grandes desafios enfrentados pela prefeitura é local para dispor estes resíduos com segurança, uma vez que as áreas disponíveis para isso tornam-se cada vez mais escassas, por vezes mais distantes dos centros de geração do lixo, elevando o custo da disposição final.

\section{2 - Registro das Condições Ambientais do Córrego do Junco:}

Em visitas à nascente do córrego do Junco, constatou-se que o pisoteio por parte do gado está acelerando dia após dia à degradação, onde a nascente está muito compactada e a degradação é total, o local tem a finalidade de servir como fonte de alimento e água para o gado que vive no local, isto é preocupante, pois através de informações de um morador local, soubese que a nascente que está localizada mais afastada da sede da fazenda é alvo de menor atenção por parte dos proprietários.

$\mathrm{Na}$ nascente do referido córrego, verifica-se que a degradação está em estágio muito acelerado, conforme observado na figura 04 , levando muitos moradores a afirmar que ali não é um córrego, mas sim um esgoto, pela quantidade de resíduos que se encontra nas águas do córrego do Junco em decorrência do despejo de dejetos feito pelo Frigorífico Santo Antônio, que causa mau cheiro e coloração escura às águas.

O principal fato que está causando a descaracterização da nascente é o pisoteio pelo gado, é notável a presença de grande mudança na coloração da água, pois no momento da visita um grande número de animais estava saindo tanto das margens da nascente quanto das margens de um açude que se formou ao longo dos anos. 
Vale ressaltar que a mudança na coloração da água não ocorre somente na nascente,verifica-se que durante seu curso, figura 4, a população local usa-o para depósito de lixo doméstico, restos de animais mortos e outros.
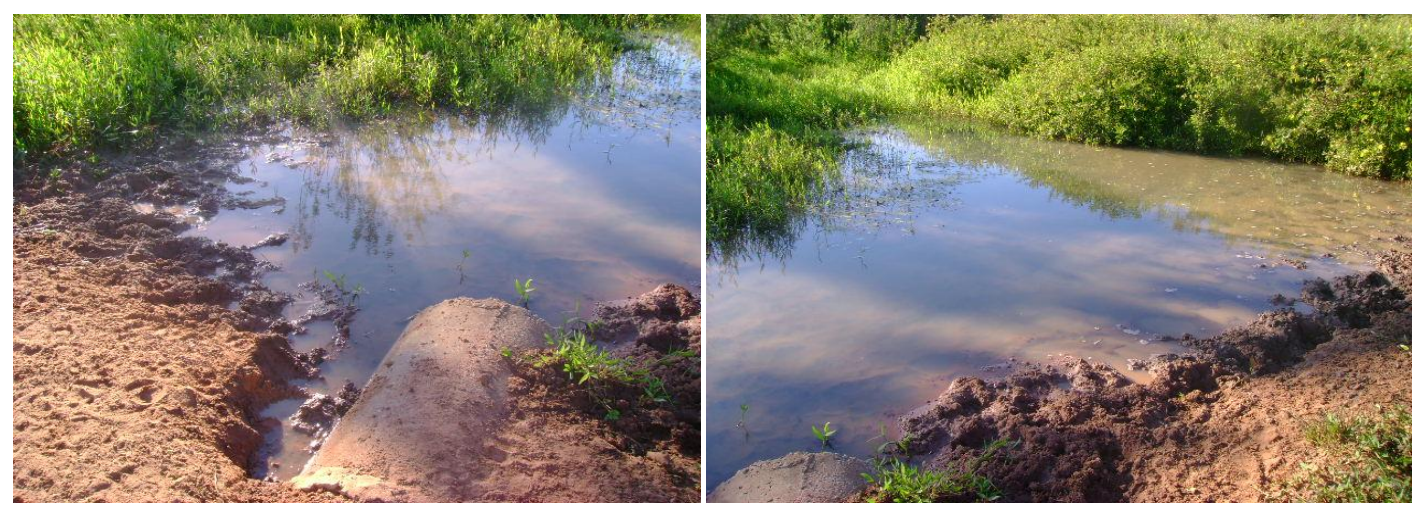

Figura 4: Vista parcial das condições físicas da nascente do córrego do Junco, Cáceres-MT.

Seguindo o percurso do córrego foi possível observar que na área urbana, bairro do Junco, reside muitas famílias, em sua maioria de baixa renda que costumam fazer uso da água do córrego para consumo e para lazer nos finais de tarde e fins de semana. Um dos mais sérios problemas ambientais é a poluição por meio do lixo dos recursos de água doce.

Também por se tratar de uma área de muitos pastos ao longo de seu percurso, é normal ver animais pastando livremente pelas ruas, exatamente por este motivo esta área demonstra maior grau de degradação, local este bastante comprometido. A margem direita do córrego foi canalizada com manilhas, formando assim uma imitação de ponte por onde as águas percorrem naturalmente, durante o período chuvoso a situação se agrava significativamente, pois a área nas proximidades é área de inundação e a capacidade das manilhas não é suficiente para tanta pressão, conforme figura 05 .

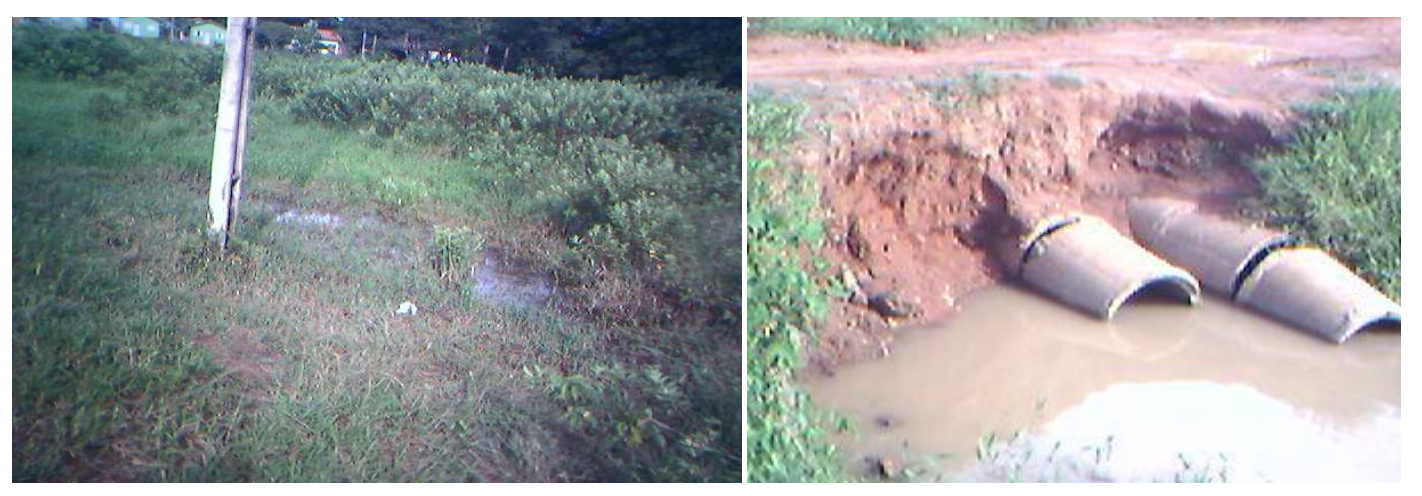

Figura 5: Vista parcial da área de inundação e canalização urbana do córrego do Junco, Cáceres-MT.

Em visita in loco, nota-se que os impactos são muito visíveis, o deságüe de resíduos provenientes do Frigorífico Santo Antônio tem aumentado a degradação, o odor é putrefato e a 
cor da água é escura, porém, cabe ressaltar que estes resíduos não são lançados diretamente no córrego, primeiro recebem um tratamento e a partir de então são despejados diretamente no solo atingindo o lençol freático e o próprio córrego aumentando a sua degradação gradativamente.

Observa-se onde o córrego corta a estrada, que os moradores do local correm risco de sofrer acidentes caso ocorra, por exemplo, o rompimento das manilhas que servem para escoar a água do córrego sob a estrada que corta o bairro, que no período chuvoso, verifica-se que o barranco está cedendo cada vez mais, onde a capacidade de suporte do local é mínima, não podendo comportar um carro de maior porte, indo ceder e causar sérios danos.

Nesta área a vegetação já não é totalmente esparsa, mesmo sendo esta área de pastagem também pode se ver outros tipos de vegetação como o cerrado, que sobreviveram a todas as ações degradáveis.

A utilização dos recursos hídricos pode gerar uma série de impactos negativos capazes de comprometer o equilíbrio ambiental e gerar diversos conflitos entre os diversos usos das águas, tanto do ponto de vista quantitativo como do ponto de vista qualitativo.

Este fato pode ser constatado, pois muitas pessoas se dirigem as ruas desertas para jogarem seus lixos em lotes baldios, provavelmente isso aconteça por falta de conhecimento, até mesmo porque não passam caminhões recolhendo os lixos da comunidade regularmente, e o maior problema que isto tem acarretado é a degradação do próprio ambiente freqüentado pela população, como já foi mencionado anteriormente há registros da presença de lixos dentro do córrego e também há presença de espumas, mesmo que ainda não seja em grandes quantidades isto é prejudicial à saúde da população, da comunidade de vegetais e para os pequenos peixes que podem ser vistos no córrego do Junco.

Observa-se também que em uma grande extensão do córrego do Junco a quantidade de Aguapé (Eichorniasp.) é enorme, esta erva aquática realiza o processo de purificação da água poluída, pois suas folhas são adstringentes, contendo $1 \%$ de cinza rica em potássio, porém isto não é suficiente para melhorar a qualidade da água, a que alguns entrevistados afirmaram ter presenciado outros moradores jogando lixo no Córrego.

As pessoas utilizam o córrego para banho, mas principalmente crianças são os maiores freqüentadores, onde pescam e praticam o lazer, algumas áreas são maiores e formam pequenas lagoas, porém há um grande risco de contaminação por doenças, uma vez que em uma das ruas de acesso ao IFMT foi construído um canal onde são depositadas grandes quantidades de lixo, e durante o período de chuva vão escoar diretamente para o curso do córrego contaminando-o.

A população contribui para a produção de lixo e não se preocupa com o destino final deste produto. Tanto nas margens como dentro do córrego do Junco percebe-se que não há preocupação da maioria das pessoas quando se refere a conservação do córrego. A preocupação 
com o que fazer com os resíduos que serão depositados deveria ter a mesma importância que se tem com a alimentação.

Na visão de Valle (1995), o controle e a minimização das fontes de poluição e o encaminhamento correto dos resíduos gerados pelas empresas e pela sociedade são as duas soluções mais efetivas e concretas para assegurar a qualidade do meio ambiente.

Na área mais próxima ao bairro Santo Antônio, encontra-se um canal mais profundo, porém, esta área está bastante poluída, nota-se a presença de óleo dentro das águas acredita-se que durante o período chuvoso poderá haver maior impacto devido os barrancos estarem se desgastando.

Em conversa com moradores, estes dizem que este ambiente não se trata de um córrego e sim de um esgoto, este fato denota a gravidade do problema porque mesmo muitas pessoas o utilizando não sabiam que este é um córrego e que deve ser conservado tanto para a utilização nos dias atuais quanto futuramente, pois desconhecem sua importância não percebendo e também não conhecendo o seu valor enquanto bem para a sociedade.

Foi possível registrar um tanque onde são jogadas as limpezas das vísceras dos animais abatidos no Frigorífico Santo Antônio, nessas lavagens são utilizados grandes quantidades de produtos químicos para proceder à limpeza destes materiais.

Procedeu-se a coleta de água que foi enviada ao Laboratório Ambiental para procederse a análise das suas condições físicas, químicas e bacteriológicas, onde no quadro 01 e 02 , registram-se os valores obtidos na referida análise.

Quadro 01: Resultado da Análise Física e Química da Água coletada no Córrego do Junco Cáceres/MT.

\begin{tabular}{|l|l|l|l|}
\hline Parâmetro & Unidade & Resultado & Padrão de Potabilidade \\
\hline Turbidez & & 24,6 & $6,0-9,5$ \\
\hline Cor & NS/CM & 100,0 & --- \\
\hline pH & Mgpt/L & 6,58 & \\
\hline Cloro Residual & $\mathrm{Mg} / \mathrm{L}$ & 0,0 & \\
\hline Alcalinidade Hidróxidos & $\mathrm{Mg} / \mathrm{L}$ & 0,0 & -- \\
\hline Alcalinidade Carbonatos & $\mathrm{Mg} / \mathrm{L}$ & 0,0 & \\
\hline $\begin{array}{l}\text { Alcalinidade } \\
\text { Bicarbonatos }\end{array}$ & & 19,8 & \\
\hline Dureza Total & & 14,1 & \\
\hline Dureza Permanente & & 0,0 & \\
\hline Dureza Temporária & & 14,1 & \\
\hline Cálcio & & 2,98 & \\
\hline Magnésio & & 7,43 & \\
\hline Sólidos Totais & & 147 & \\
\hline Sólidos Dissolvidos & & 89 & \\
\hline Sólidos Suspensos & & 58 & \\
\hline Ferro & & 3,38 & \\
\hline Cloretos & 15,26 & \\
\hline Condutividade & & 77,6 & \\
\hline
\end{tabular}


No que se refere à análise física e química, o laudo do especialista registra "em relação aos parâmetros avaliados, de acordo com a Resolução CONAMA $n^{\circ} 357$, de 17 de março de 2005, com exceção do valor da Cor, a amostra analisada atende as condições que a caracterizam como água doce, classe 2, com as seguintes utilizações previstas: abastecimento doméstico, após tratamento convencional, proteção das comunidades aquáticas; recreação de contato primário, conforme CONAMA 274 de 2000; irrigação de hortaliças e plantas frutiferas; aqüicultura e atividades de pesca".

Quadro 02: Resultado da Análise Bacteriológica da Água coletada no Córrego do Junco - Cáceres/MT.

\begin{tabular}{|l|l|l|l|}
\hline Parâmetro & Unidade & Resultado & Padrão de Potabilidade \\
\hline Coliformes totais & NMP/100ml & 4.300 & Ausente \\
\hline Coliformes Fecais & NMP/100ml & 1.250 & Ausente \\
\hline
\end{tabular}

Entretanto, no que se refere ao exame bacteriológico, o laudo registra: "Água nãa potávelde acordo com a portaria $n^{\circ} 518$ de 25 de março de 2004 do Ministério da Saúde, em relação aos parâmetros físico-químicos e bacteriológicos analisados”.

Esses resultados, obtidos por meio de laudo do Laboratório Ambiental, indicam que medidas devem ser tomadas quanto à utilização das águas do referido córrego pela população local e também pelo Frigorífico, uma vez que o mesmo está infringindo o Código Ambiental.

\section{5 - CONSIDERAÇÕES FINAIS}

Com o crescimento populacional de Cáceres o lixo torna-se um dos problemas que vem tendo proporções enormes, tendo passado por várias administrações municipais, não sendo resolvido os aspectos relacionados ao destino final dos resíduos sólidos em nossa cidade, mas a situação continua gritante.

As soluções para o problema do lixo urbano são várias, dependendo da fonte poluidora. Já no caso do lixo orgânico domiciliar o ideal seria a construção de usinas de compostagem para o processamento do lixo orgânico destinado à produção de metano e de adubo orgânico. Entretanto para o lixo inorgânico, o ideal seria a coleta seletiva, que possibilitaria a reciclagem de grande parte dos materiais contidos no lixo domiciliar e industrial. Materiais como vidros, plásticos, latas de alumínios e latão, papeis e vários outros metais podem ser reciclados.

A presença dos resíduos sólidos municipais nas áreas urbanas é muito significativa, gerando problemas de ordem estética, de saúde pública, pelo acesso a vetores e animais domésticos, obstruindo rios, canais e redes de drenagem urbana, provocando inundações e potencializando epidemias de dengue e de leptospirose, entre outras. 
Assim, torna-se necessário para o município de Cáceres, a elaboração e efetivação de projetos e programas de gestão de resíduos sólidos que estão depositados a céu aberto na forma de "lixão", uma vez que essa área está localizada na bacia hidrográfica do córrego das Piraputangas. As águas desse córrego abastecem os moradores dos vários sítios e é freqüentado por turistas nos finais de semana, sendo utilizado também como área de lazer.

No que se refere ao córrego do Junco, é importante alertar a comunidade para os riscos, analisando-se as entrevistas, os moradores se preocupam, pois muitos percebem a importância do córrego, porém, muitos não estão dispostos a fazes algo que auxiliem na conservação do ambiente. Ao observar as condições atuais, nota-se que está havendo um descaso muito grande principalmente por parte das autoridades, a degradação, ou seja, os maiores impactos se desencadeiam a partir da nascente e consequentemente existem outros fatores que acabam favorecendo fatalmente com a aceleração destes, a exemplo pode-se citar a quantidade de lixo dentro do curso do córrego e também nas suas margens.

\section{REFERÊNCIAS BIBLIOGRÁFICAS}

CONTE, M. de L.. LEOPOLDO, P. R.Avaliação de Recursos Hídricos: Rio Pardo um exemplo. São Paulo. Editora UNESP, 2001.

COUTINHO, R. do L.; ROCCO, R.O Direito Ambiental das Cidades. Rio de Janeiro: DP\&A, 2004.

ESTEVES, F. de A. Fundamentos de Limnologia. $2^{\text {a }}$ ed. Rio de Janeiro: Interciência, 1998.

FIGUEIREDO, G. J. P. de. Direito Ambiental e a Saúde dos Trabalhadores. São Paulo. LTr 2000.

GUERRA, A; CUNHA, S. Impactos Ambientais Urbanos no Brasil. Rio de Janeiro: Bertrand Brasil, 2001. 420 p.

MÜLlER-PLANTENBERG, Clarita; AB'SABER, Aziz Nacib. Previsão de Impactos. $2^{\mathrm{a}}$ edição. São Paulo. Editora USP, 2002

OLIVEIRA, J. F de; JUNIOR, O. A. dos S; MARTINEZ, C. A. Saneamento básico na Baixada - direito à cidade - direito à vida - Rio de Janeiro-RJ: FASE - Federação de Órgãos para Assistência Social e Educacional. Comitê Político de Saneamento e Meio Ambiente na Baixada Fluminense, 1991.

TUNDISI, J. G. Água no Século XXI: Enfrentando a Escassez, São Carlos: RIMA IIE, 2003.

VALLE, C. E. do. Qualidade Ambiental: O desafio de ser competitivo protegendo o meio ambiente. São Paulo: Pioneira, 1995. 